\title{
ELECTRICAL ACTIVITY OF THE EYE IN HIGH MYOPIA*
}

\author{
BY \\ R. K. BLACH, BARRIE JAY, AND HELGA KOLB \\ Department of Experimental Ophthalmology, Institute of Ophthalmology, University of London
}

IT Is generally agreed that simple myopia and degenerative myopia are separate conditions, the former being a normal chance variant in the biological series which includes emmetropia and hypermetropia (Duke-Elder, 1949) and the latter a pathological condition. Degenerative myopia in its advanced stage consists of an association of defects: a highly myopic refraction, chorio-retinal degeneration and atrophy, thinning of the posterior sclera, and an increased axial length of the eye. Additional defects, such as cupuliform cataract, glaucoma, and retinal detachment, are relatively common in patients with degenerative myopia, and a hereditary element is often present. In the investigation here reported the function of eyes with degenerative myopia has been studied using electroretinography and electro-oculography.

Although degenerative myopia may be congenital, it usually takes many years to develop. In its early stages a myopic refraction, straight temporal vessels, and a temporal crescent at the optic disc may be the only physical signs, and these cannot be distinguished from cases of simple myopia (Blach, Jay, and MacFaul, 1965). It is hoped that the electrical tests described here may prove to be of some diagnostic and prognostic value, and be of some help in pointing to the primary defect in degenerative myopia.

\section{Review}

Karpe (1945) performed ERGs on four eyes with high myopia; in three the ERG was definitely subnormal, while in the last it was probably subnormal. François and de Rouck (1954) studied the ERG in patients with both simple and degenerative myopia; those with simple myopia had normal ERGs, while in 75 per cent. of those with high myopia the $b$ waves were depressed and the $a$ waves varied from strongly positive to completely absent. They claimed that the ERG changes preceded the ophthalmoscopic changes in degenerative myopia, although they classified degenerative myopia by the fundus changes. They found no correlation between the amplitude of the $b$ wave and the degree of myopia. From the changes occurring in the $b$ waves, they argued that the retina rather than the choroid was primarily involved in this disease. Franceschetti, Dieterle, and Schwarz (1960) investigating fourteen cases of uniocular myopia, found that the $b$ waves were reduced in the scotopic ERG and that this reduction was related to the degree of myopia. Jayle and Boyer (1960) found that myopic patients with good visual function had normal ERGs, while those with poor visual function had subnormal ERGs; they suggested that the photopic system was involved before the scotopic system. Ponte (1962) found that in simple myopia the mean amplitude of the $b$ wave was slightly reduced, while in severe myopia the ERG was considerably affected, the most frequent finding being a subnormal ERG of negative type.

François, Verriest, and de Rouck (1956) examined four patients with high myopia and pronounced choroidal changes and found that the resting potential level was normal. On the other hand, Arden, Barrada, and Kelsey (1962) performed EOGs on a number of patients with high myopia and found that the light-rise was seldom as great as the normal

\footnotetext{
- Received for publication July 15, 1965.
} 
mean, and was frequently about or below the normal lower limit. In those cases in which myopic degeneration was obvious, very low light rises occurred.

\section{Material and Methods}

Subjects.-35 patients with degenerative myopia were referred from the Myopia Clinic"of Moorfields Eye Hospital to the Electrodiagnostic Clinic at the Institute of Ophthalmology for assessment of retinal function. Four of these patients had uniocular myopia. All had undergone a comprehensive ophthalmological examination before referral, and were graded clinically into three types according to the degree of chorio-retinal degeneration.

Electro-oculograms were performed on all the patients in this series, and electroretinograms were performed on those patients who were not too young or too nervous for this test to be carried out. Dark adaptation was measured on the majority of the patients in this series.

Electro-oculogram (EOG).- The apparatus and procedure used for recording the EOGs are those described previously by Arden and co-workers (Arden and Kelsey, 1962, a, b; Arden and others, 1962; Arden and Barrada, 1962).

The ratio $\frac{\text { light peak }}{\text { dark trough }} \times 100$ was calculated for each subject. In a recent calculation of normal values for the EOG (47 subjects aged from 10 to 80 years), the mean EOG ratio was found to be 238 per cent. (S.E. \pm 3.7 ), but as there is a negative correlation with age the extreme limits of normal are 290 and 180 per cent.

These values of the resting potential are not measured in absolute units because of the error introduced by the position of the electrodes, an error apparent even on measuring the ratio in the two eyes of the same individual. Arbitrary units are therefore used and these are calculated by measuring the ratio of the size of the recording in $\mathrm{mm}$. in the dark trough as compared with the light peak.

Electroretinogram (ERG).- A Karpe scleral contact lens was used. The recordings were produced on a Mingograph Ink-Spraying Polygraph machine at a paper speed of $5 \mathrm{~cm} . / \mathrm{sec}$. and at a time constant of $2 \mathrm{sec}$. Top cuts were used as desired. The usual upper frequency was $120 \mathrm{c} / \mathrm{s}$.

The stimulating light was a tungsten filament lamp $(250 \mathrm{v}, 150 \mathrm{w})$ housed in a modified camera, with a hand-operated shutter to produce single square pulses of light. The single camera lens magnified the filament image to give an intense stimulus covering the whole pupil. The subject's pupil was dilated with homatropine and cocaine 2 per cent. Neutral density filters inserted over the camera lens allowed the stimulating light intensity to be reduced in log unit steps. Under conditions of maximal intensity the ERG produced in the normal eye is large, with a well-defined $a$ wave and a sharp $b$ wave. Rod activity, however, is not suppressed as the growth and rounding of the $b$ wave is seen during dark adaptation. Several ERG recordings were made under conditions of normal room lighting and then the patient was dark-adapted. The $b$ wave reaches its maximum amplitude after approximately 20 minutes of dark adaptation. The average dark-adapted ERG for a normal subject has an $a$ wave of $100-200 \mu \mathrm{V}$ in amplitude, and a $b$ wave of between 400 and $500 \mu \mathrm{V}$.

Dark Adaptation.-This was measured on a Goldman-Weekers dark adaptometer. The standard $7^{\circ}$ area at $11^{\circ}$ eccentricity was used.

Clinical Evaluation.-The degree of myopic degeneration was graded independently by two of us (R.K.B., B.J.) judged on the degree and area of atrophy of the posterior fundus as seen clinically and with fundus photographs.

\section{Results}

Electro-oculography.-The frequency distribution histogram of the EOG ratios from patients with degenerative myopia compared with the distribution for subjects with normal eyes is given in Fig. 1, opposite. The EOG ratios for myopic eyes lie between 125 and 230 per cent. light-rise, and the majority of the results fall outside 
the normal limits. The mean EOG ratio for the myopic group is 176 per cent. (S.E. $\pm 3 \cdot 2$ ) compared with the normal mean of 238 per cent. (S.E. $\pm 3 \cdot 7$ ).

FIG. 1.-Summary of EOG findings in myopes compared with normal subjects. Linear plot.

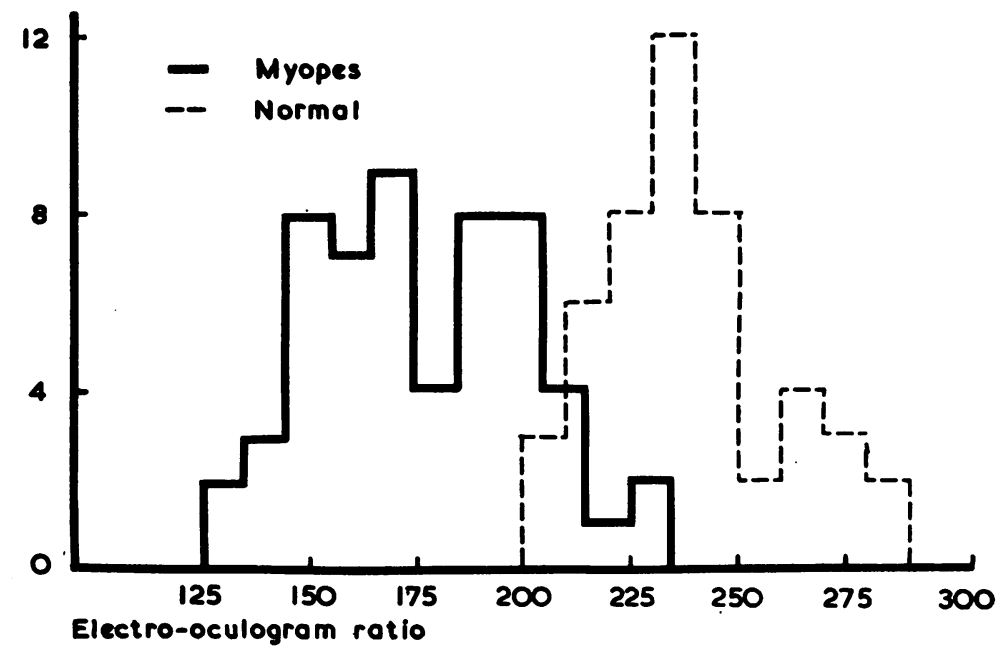

In calculating the statistics, data from the two eyes of patients with bilateral degenerative myopia have been used as independent readings. This is because the differences in refractive error and degree of chorio-retinal degeneration between the two eyes were often great enough to warrant treating the two eyes independently.

The distribution of the EOG ratios for myopic eyes plotted against age is given in Fig. 2. Although some of the results fall near the lower limit for normal eyes, the

FIG. 2.-Correlation between EOG ratio and age (solid black line) in myopes compared with normal subjects (dashed line). Most of the myopes lie about or below the lower limit of normal. Note also the lower EOG ratio in the myopic eye of the uniocular myopes.

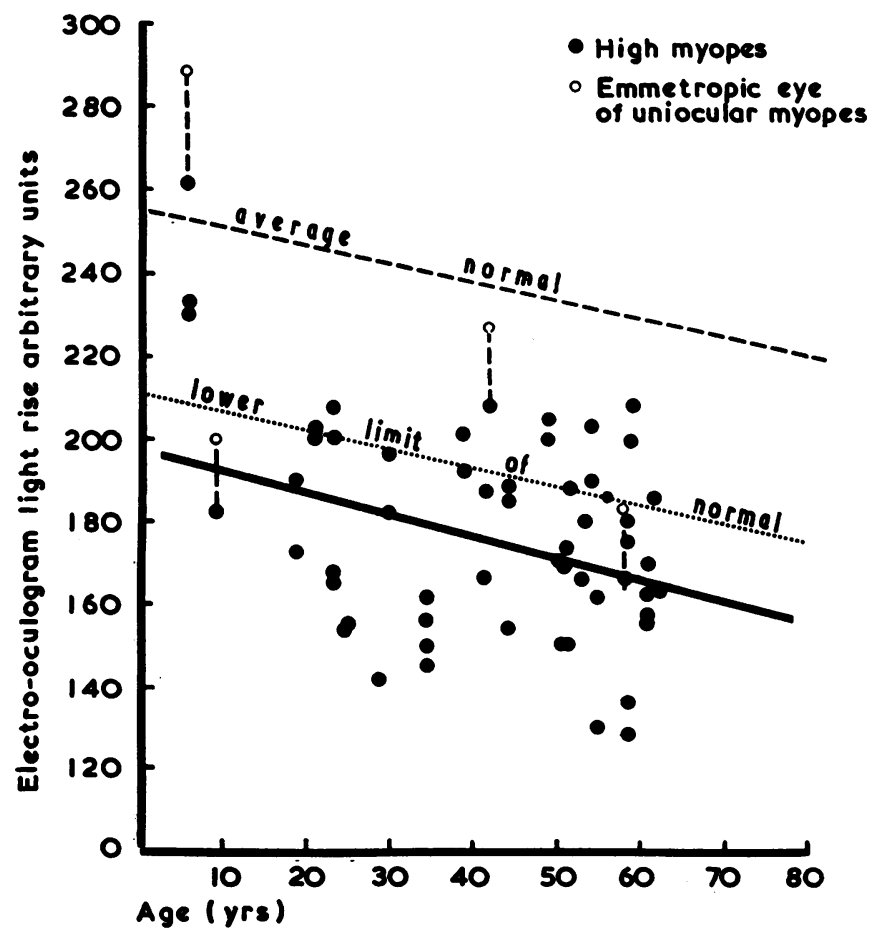


majority of the results are below the lower limit of normal. There is a correlation between the EOG ratios for normal eyes with age, and the regression line for this lies along the average normal line ( $R=-0.36$ for 45 d.f.; $b=-0.42)$. Similarly, the myopic eyes show a decrease of the EOG ratio with age, and the regression line is indicated in Fig. $2(\mathrm{R}=-0.335$ for 52 d.f.; $b=-0.5166)$.

A $t$ test performed on the results of the EOG ratios of patients with degenerative myopia and subjects with normal eyes shows a significant difference between the two groups $(t=4 \cdot 2 ; \mathrm{P}<0.001$ for 99 d.f.).

Further analysis of the EOG results for myopic eyes reveals the following:

(1) Sex Differences in the EOG Ratios.-There is no significant difference between the EOG ratios for men and for women among patients with degenerative myopia (Table I).

TABLE I

EOG Ratios Related to SeX

\begin{tabular}{l|c|c}
\hline \multicolumn{1}{c|}{ Sex } & Male & Female \\
\hline Mean EOG Ratio (per cent.) & 180 (S.E. $\pm 5 \cdot 8)$ & 175 (S.E. $\pm 3 \cdot 8)$ \\
\hline No. of Subjects & 22 & 35 \\
\hline & $t=0.746$ & \\
\hline
\end{tabular}

(2) EOG Ratios and Refractive Error.-There is no relationship between the EOG ratio and the degree of refractive error (Fig. 3).

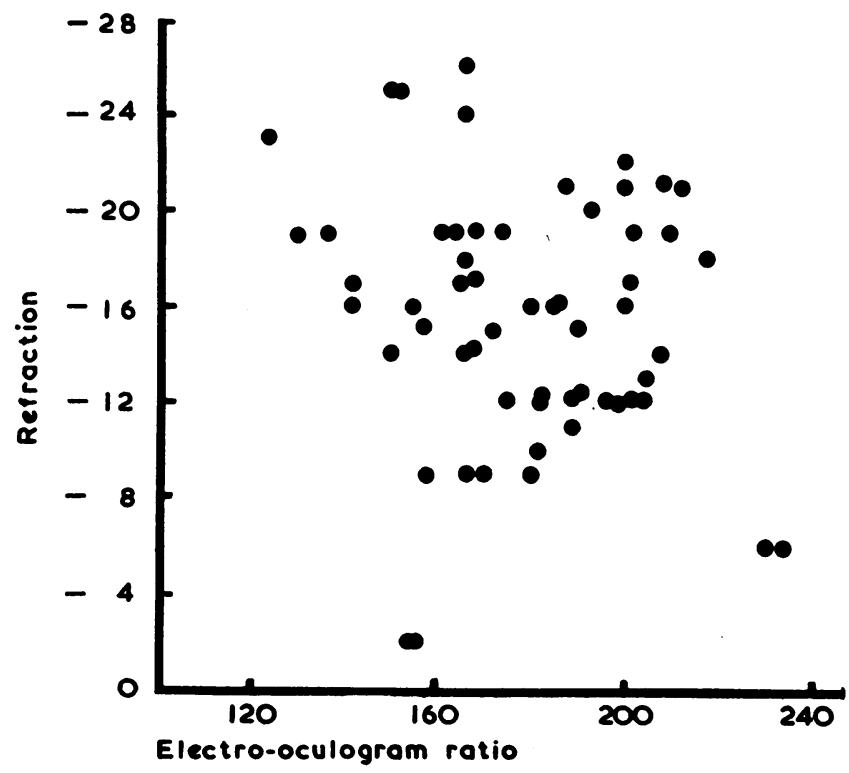

Fig. 3.-Correlation between EOG ratio and refractive error in myopes. Scatter diagram shows correlation to be very poor.

(3) EOG Ratios in Patients with and without a Family History of Myopia.-There is no significant difference between these two groups (Table II, opposite). 
TABLE II

EOG RATIOS RELATED to FAMILy History

\begin{tabular}{l|c|c}
\hline \multicolumn{1}{c|}{ Family History } & Present & Absent \\
\hline Mean EOG Ratio (per cent.) & 182 & 181 \\
\hline No. of Subjects & 45 & 15 \\
\hline S.E. & \pm 3.0 & $\pm 9 \cdot 2$ \\
\hline
\end{tabular}

(4) EOG Ratios and Colour of Iris.-Patients with degenerative myopia were divided into two groups depending on whether they had heavily pigmented irides (hazel to brown) or lightly pigmented irides (blue, green, and grey). The results are presented in Table III and a $t$ test performed on these two groups reveals a significant difference between them.

TABLE III

EOG RATIOS RELATED to COLOUR OF IRIS

\begin{tabular}{l|c|c}
\hline \multicolumn{1}{c|}{ Iris } & Heavily Pigmented & Lightly Pigmented \\
\hline Mean EOG Ratio (per cent.) & 189 & 174 \\
\hline No. of Subjects & 35 & 27 \\
\hline Mean Age of Group (yrs) & 42 & 39 \\
\hline S.E. & \pm 5.3 & \pm 5.0 \\
\hline Significance between Means & $t=2.0$ & $P=0.05$ \\
\hline
\end{tabular}

(5) EOG Ratios related to ERG Results.-A large proportion of patients with degenerative myopia gave abnormal ERGs (see below) and the EOG ratios of this group were compared with the group that had normal ERGs. There was no significant difference between the two groups (see Table IV). A direct correlation between the EOG ratio and amplitude of the $b$ wave proved to be insignificant, as also did a correlation between EOG and $a$ wave amplitude.

EOG ratio/ $b$ wave amplitude $R=0.078$

EOG ratio/ $a$ wave amplitude $\mathrm{R}=0.29$

TABLE IV

EOG Ratios RELATED to ERG

\begin{tabular}{l|c|c}
\hline \multicolumn{1}{c|}{ ERG } & Abnormal & Normal \\
\hline Mean EOG Ratio (per cent.) & 174 & 177 \\
\hline No. of Subjects & 41 & 17 \\
\hline S.E. & \pm 4.5 & \pm 5.4 \\
\hline Significance between Means & $t=0.45$ & insignificant \\
\hline
\end{tabular}


(6) EOG Ratios related to Dark Adaptation.-A minority of patients with degenerative myopia proved to have abnormal dark adaptation, and this group had a lower mean EOG ratio than the group with normal dark adaptation (Table V). A $t$ test performed on the group means revealed the difference to be statistically significant.

TABLE V

EOG Ratios Related to Dark Adaptation

\begin{tabular}{l|c|c}
\hline \multicolumn{1}{c|}{ Dark Adaptation } & Normal & Elevated Threshold \\
\hline Mean EOG Ratio (per cent.) & 184 & 157 \\
\hline No. of Subjects & 55 & 12 \\
\hline S.E. & \pm 4.0 & \pm 8.2 \\
\hline Significance between Means & $t=9 \cdot 3$ & $\mathbf{P}=<0.001$ \\
\hline
\end{tabular}

(7) EOG Ratios related to Degree of Degenerative Fundus Change.-The fundus changes in patients with degenerative myopia were classified clinically as early, moderate, or advanced, depending upon the degree of disturbance of the pigment epithelium of the retina or of chorio-retinal atrophy. The EOG ratios of the patients in these groups showed a significantly decreasing value with increasing extent of degenerative changed (Table VI), which indicates that the EOG ratio is related to the degree of degenerative change in the fundus.

TABLE VI

EOG Ratios Related to Degree of Myopic Degeneration

\begin{tabular}{|c|c|c|c|}
\hline Degree of Degeneration & Early & Moderate & Advanced \\
\hline No. of Patients & 23 & 24 & 15 \\
\hline Mean EOG (per cent.) & 199 & 182 & 159 \\
\hline S.D. & 34 & 17 & 17 \\
\hline S.E. & $\pm 7 \cdot 2$ & $\pm 3 \cdot 6$ & $\pm 4 \cdot 4$ \\
\hline $\begin{array}{l}\text { Significance between } \\
\text { Early/Moderate }\end{array}$ & \multicolumn{3}{|c|}{$t=2.1 ;$ significant to $P=0.05$} \\
\hline Moderate/Advanced & \multicolumn{3}{|c|}{$t=4.1 ;$ significant to $P<0.001$} \\
\hline
\end{tabular}

Electroretinography.-ERGs were performed on all patients over the age of 10 years. The amplitudes of the $a$ and $b$ waves of the fully dark-adapted ERG, and the rate of growth of the $b$ wave during the course of dark adaptation, were measured in all patients.

The frequency distributions of the $a$ and $b$ waves of the scotopic ERG of normal subjects is given in Fig. 4 (opposite). The distribution of the $b$ wave is more skewed than that of the $a$ wave, but there is good correlation between the two ( $R=0.419)$. The following average values have been calculated from a group of 25 normal subjects:

$$
\begin{array}{llll}
\text { Mean } a \text { wave } & 176 \mu \mathrm{V} ; & \text { S.D. } 73 \mu \mathrm{V} ; & \text { S.E. } \pm 14 \cdot 6 \\
\text { Mean } b \text { wave } & 448 \mu \mathrm{V} ; & \text { S.D. } 134 \mu \mathrm{V} ; & \text { S.E. } \pm 27
\end{array}
$$

Because of this variance, and in view of the correlation between the $a$ and $b$ waves, we consider it more valuable to define the normal ERG waveform, for our conditions 


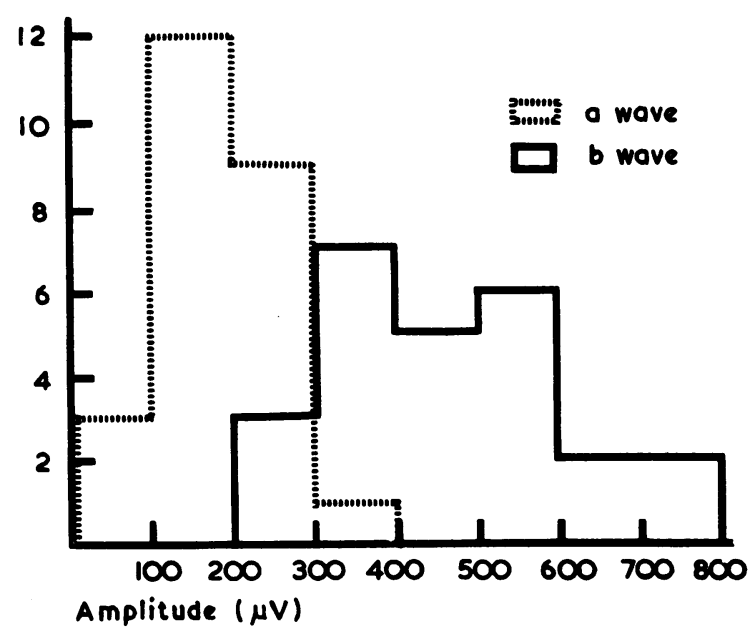

FIG. 4.-Histogram of the $a$ and $b$ wave distributions in normal subjects. Linear plot.

FIG. 5.-Extreme types of waveform recorded from myopes compared with a recording from a normal subject (A). The ERG waveform in the early to moderate myope can vary from supernormal (B) to negative (C). In the severe myope the waveform can be negative with a very enlarged $a$ wave (D) to minute in amplitude (E). The EOG findings in these particular patients are indicated. Scale same for all recordings.

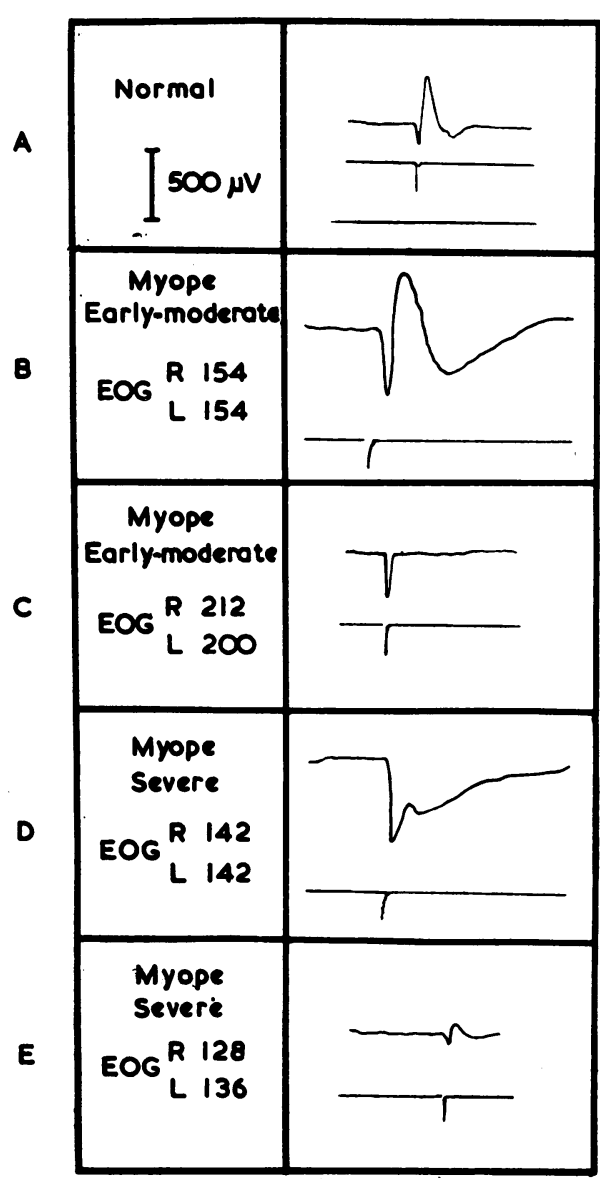

of testing, as the ratio of the amplitude of the $a$ wave to that of the $b$ wave. In normal eyes this ratio is approximately 40 per cent.

The ERGs in patients with degenerative myopia vary from those that are normal in waveform and amplitude to those that are negative or reduced in amplitude (Fig. 5). The most abnormal ERG was recorded from a 58-year-old woman with advanced degenerative fundus changes; the $b$ wave was reduced in amplitude and the $a$ wave appeared correspondingly enlarged. In another case a negative ERG was produced with $a$ and $b$ waves of identical size at the end of 30 minutes of dark adaptation; the $b$ wave never rose above the baseline. It is interesting that in this patient the EOG ratios were normal. In one patient with only moderate degenerative changes in the fundi the $a$ wave was greatly enlarged and the EOG ratio was reduced, and in another patient with early degenerative changes in the fundi the ERG was supernormal.

The majority of the patients with degenerative myopia gave ERGs with deep $a$ waves and reduced $b$ waves. The average values calculated from these patients are:

Mean $a$ wave $224 \mu \mathrm{V}$; S.D. $113 \mu \mathrm{V} ;$ S.E. $\pm 20 \cdot 5$

Mean $b$ wave $372 \mu \mathrm{V} ;$ S.D. $135 \mu \mathrm{V} ;$ S.E. \pm 24

$a$ wave as per cent. of $b$ wave $=60$ per cent. 
These values are significantly different from the normal values (see Table VII and compare Fig. 6 with Fig. 4). It is interesting to note that the reduced $b$ wave in the myopic eye is particularly apparent when the recordings of ERGs under conditions of reduced light stimulus intensity ( 2 log units) are compared with the normal.

TABLE VII

ERG Amplitudes in Normal ANd Myopic SubJects

\begin{tabular}{l|c|c|c}
\hline \multicolumn{1}{c|}{ Patients } & $a$ wave & $b$ wave (0 L.U.) & $b$ wave (2 L.U.) \\
\hline Normals (25) & $176 \mu \mathrm{V}$ & $448 \mu \mathrm{V}$ & $237 \mu \mathrm{V}$ \\
\hline Myopes (30) & $224 \mu \mathrm{V}$ & $372 \mu \mathrm{V}$ & $151 \mu \mathrm{V}$ \\
\hline Difference between means & $t=1.8$ & $t=2.1$ & $t=3.8$ \\
\hline Significance 53 d.f. & $\mathbf{P}>0.05$ & $\mathrm{P}=0.05$ & $\mathrm{P}=0.001$ \\
\hline
\end{tabular}

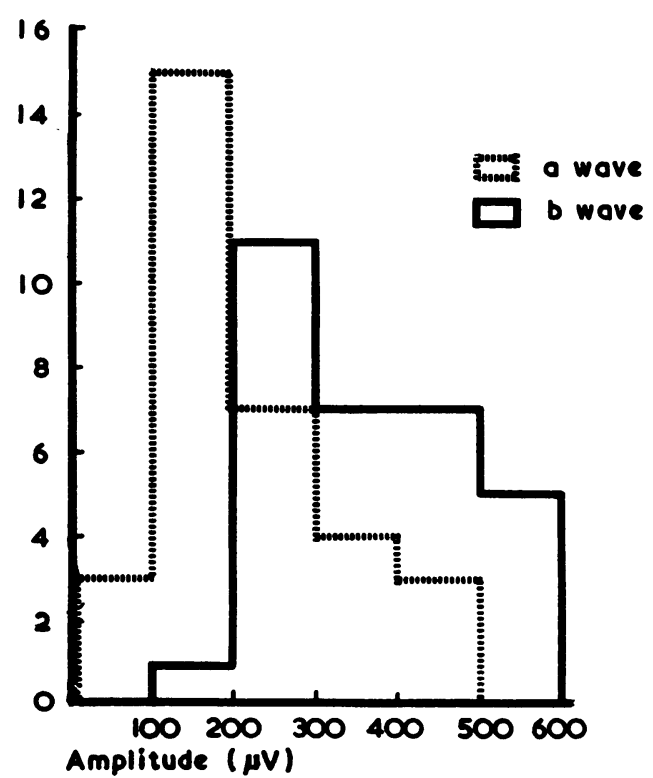

Fig. 6.- Histogram of $a$ and $b$ wave distribution in myopes. Linear plot. Note larger amplitudes of the $a$ waves compared with those of normal subjects (Fig. 4).

There is also a positive correlation $(R= \pm 0.67)$ between the amplitudes of the $a$ and $b$ waves in the myopic patients which suggests that the $a$ wave and $b$ wave are equally affected. The regression line calculated from this data is shown (opposite) in Fig. $7(b=0.5586)$. The regression line calculated from the normal $a$ and $b$ waves is shown as a dotted line $(b=0 \cdot 23)$. The steeper slope of the regression line for the myopes indicates an abnormal relationship between the $a$ and $b$ waves in these patients' ERGs. The relationship between the ERG and the visible degenerative state of the fundus can be seen only by gross averaging of the data but the groups become too small for statistical analysis.

$\begin{array}{ccccc} & \text { Early } & \text { Moderate } & \text { Advanced } & \text { Normal } \\ \text { Mean } b \text { wave } & 390 \mu \mathrm{V} & 383 \mu \mathrm{V} & 326 \mu \mathrm{V} & 448 \mu \mathrm{V} \\ \text { Mean } a \text { wave } & 201 \mu \mathrm{V} & 248 \mu \mathrm{V} & 183 \mu \mathrm{V} & 176 \mu \mathrm{V} \\ a \text { wave as percentage of } b \text { wave } & 52 & 65 & 56 & 40\end{array}$




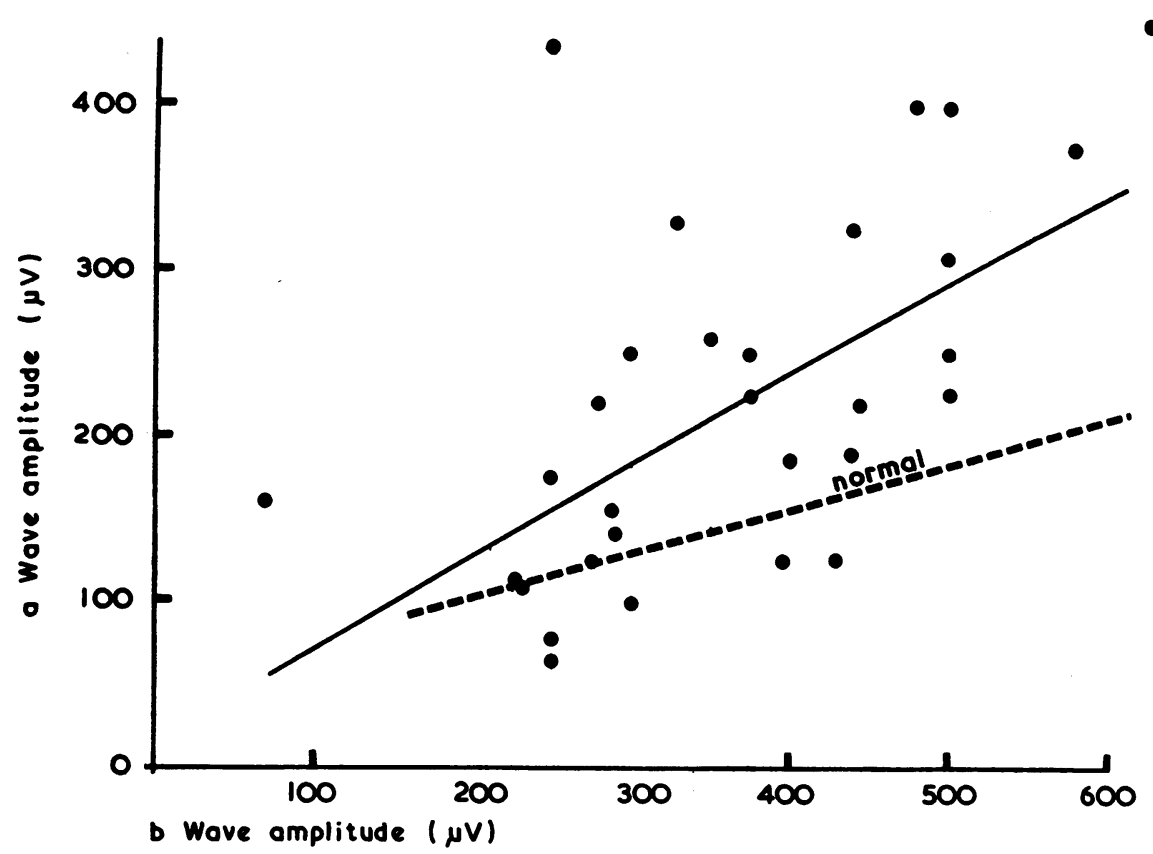

FIG. 7.-Correlation between $a$ and $b$ wave amplitude in myopes (solid line). Relationship between $a$ and $b$ waves for normal subjects (dotted line) is shown for comparison.

However, the implications are that the first sign of change in the ERG is an apparent increased negativity and then the $a$ and $b$ waves decrease in proportion to the degenerative changes visible in the retina.

Dark Adaptation.--Eleven of the 29 patients tested for dark adaptation proved to have abnormal adaptation, nine of these presenting an elevated rod threshold. The results of this and other electrical tests in these nine patients are presented in Table VIII (overleaf). Five patients did not show any cone/rod knee ( $\alpha$ point) but two of these gave normal final thresholds.

\section{Uniocular Myopes}

Four patients in this series had uniocular degenerative myopia. The EOG ratios for each eye are included in Fig. 2, and these and other results are summarized in Table IX (overleaf). The difference between the findings in the myopic and normal eye clearly indicate pathology of the degenerative eye.

\section{Discussion}

In discussing the results of this investigation we have attempted to relate the pathology of degenerative myopia to the known significance of the electrical findings.

A characteristic feature of eyes with degenerative myopia is that areas of normal retina and choroid, areas of partial degeneration, and areas of complete chorioretinal atrophy may be found in the same eye in varying proportions. This accounts for the difficulty in the clinical grading of degenerative myopia and stands in contrast to the electrical findings which represent the activity of the whole eye. It is known 
TABLE VIII

Results of Electro-Diagnostic Tests on all the Patients that showed Changes in the Dark Adaptation Test (Goldmann/Weekers Adaptometer)

\begin{tabular}{|c|c|c|c|c|c|c|c|}
\hline $\begin{array}{l}\text { Case } \\
\text { No. }\end{array}$ & $\begin{array}{l}\text { Age } \\
\text { (yrs) }\end{array}$ & Sex & Refraction & $\begin{array}{c}\text { Extent of } \\
\text { Pigmentary } \\
\text { Degeneration }\end{array}$ & $\begin{array}{c}\text { EOG } \\
\text { (per cent.) }\end{array}$ & ERG & Dark Adaptation \\
\hline 1 & 23 & $\mathbf{F}$ & $\begin{array}{l}R-24 \\
L-26\end{array}$ & Severe & $\begin{array}{l}R 166 \\
L \\
L\end{array}$ & $\begin{array}{l}\text { L eye: scotopic } \\
a \text { wave } 100 \mu \mathrm{V} \\
\text { scotopic } b \text { wave }\end{array}$ & $\begin{array}{l}\text { L eye: Rod threshold } \\
\text { elevated } 1.5 \mathrm{LU} \\
\text { Slow adaptation } \\
\alpha \text { point missing }\end{array}$ \\
\hline 2 & 44 & $\mathbf{M}$ & $\begin{array}{l}R-12 \\
L-11\end{array}$ & Severe & $\begin{array}{l}\text { R } 188 \\
\text { L } 188\end{array}$ & $\begin{array}{l}\text { R eye: scotopic } \\
a \text { wave } 68 \mu \mathrm{V} \\
\text { scotopic } b \text { wave } 250 \mathrm{uV}\end{array}$ & $\begin{array}{l}\text { R eye: Threshold elevated } \\
1 \mathrm{LU} \\
\alpha \text { point missing }\end{array}$ \\
\hline 3 & 58 & $\mathbf{F}$ & $\begin{array}{l}R-23 \\
L-19\end{array}$ & Severe & $\begin{array}{l}\text { R } 128 \\
\text { L } 136\end{array}$ & $\begin{array}{l}\text { R eye: scotopic } \\
a \text { wave } 72 \mu \mathrm{V} \\
\text { scotopic } b \text { wave } 161 \mu \mathrm{V}\end{array}$ & $\begin{array}{l}\text { R eye: Threshold } \\
\text { elevated } 1 \cdot 5 \mathrm{LU} \\
\text { Slow adaptation }\end{array}$ \\
\hline 4 & 58 & $\mathbf{M}$ & $\begin{array}{l}\mathbf{R}-16 \\
\mathbf{L}-12\end{array}$ & Severe & $\begin{array}{l}\mathbf{R} 180 \\
\mathrm{~L} 175\end{array}$ & $\begin{array}{l}\text { L eye: scotopic } \\
a \text { wave } 324 \mu \mathrm{V} \\
\text { scotopic } b \text { wave } 440 \mu \mathrm{V}\end{array}$ & $\begin{array}{l}\text { L eye: Threshold } \\
\text { elevated } 1 \text { LU } \\
\text { Slow adaptation }\end{array}$ \\
\hline 5 & 53 & $\mathbf{F}$ & $\begin{array}{l}R-9 \\
L-9\end{array}$ & Severe & $\begin{array}{l}\text { R } 180 \\
\text { L } 166\end{array}$ & $\begin{array}{l}\text { R eye: scotopic } \\
a \text { wave } 375 \mu \mathrm{V} \\
\text { scotopic } b \text { wave } 580 \mu \mathrm{V}\end{array}$ & $\begin{array}{l}\text { L eye: Very slow } \\
\text { adaptation } \\
\text { Final threshold elevated } \\
\frac{1}{2} L U \\
\alpha \text { point missing }\end{array}$ \\
\hline 6 & 34 & $\mathbf{M}$ & $\begin{array}{l}\mathbf{R}-17 \\
\mathbf{L}-17\end{array}$ & Early & $\begin{array}{l}\text { R } 162 \\
\text { L } 145\end{array}$ & $\begin{array}{l}\text { L eye: scotopic } \\
a \text { wave } 175 \mu \mathrm{V} \\
\text { scotopic } b \text { wave } 250 \mu \mathrm{V}\end{array}$ & $\begin{array}{l}\text { L eye: Threshold } \\
\text { elevated } 1 \mathrm{LU}\end{array}$ \\
\hline 7 & 38 & $\mathbf{F}$ & $\begin{array}{l}\mathbf{R}-20 \\
\mathbf{L}-19\end{array}$ & Medium & $\begin{array}{l}\text { R } 193 \\
\text { L } 202\end{array}$ & $\begin{array}{l}\text { R eye: scotopic } \\
a \text { wave } 400 \mu \mathrm{V} \\
\text { scotopic } b \text { wave } 480 \mu \mathrm{V}\end{array}$ & $\begin{array}{l}\text { L eye: Threshold } \\
\text { elevated } 1 \mathrm{LU}\end{array}$ \\
\hline 8 & 28 & $\mathbf{M}$ & $\begin{array}{l}\mathbf{R}-16 \\
\mathbf{L}-17\end{array}$ & Medium & $\begin{array}{l}\text { R } 142 \\
\text { L } 142\end{array}$ & $\begin{array}{l}\text { L eye: scotopic } \\
a \text { wave } 435 \mu \mathrm{V} \\
\text { scotopic } b \text { wave } 250 \mu \mathrm{V}\end{array}$ & $\begin{array}{l}\text { R eye: Threshold elevated } \\
1 \frac{1}{2} \text { LU } \\
\text { L eye: Threshold elevated } \\
1 \text { LU }\end{array}$ \\
\hline 9 & 29 & $\mathbf{F}$ & $\begin{array}{l}\mathbf{R}-24 \\
\mathbf{L}-21\end{array}$ & $\begin{array}{l}\text { Medium } \\
\text { Leye partial } \\
\text { detachment }\end{array}$ & $\begin{array}{l}\text { R } 170 \\
\text { L no } \\
\text { light rise }\end{array}$ & $\begin{array}{l}\text { L eye: scotopic } \\
a \text { wave } 185 \mu \mathrm{V} \\
\text { scotopic } b \text { wave } 270 \mu \mathrm{V}\end{array}$ & $\begin{array}{l}\text { R eye: Normal } \\
\text { L eye: Threshold } \\
\text { elevated } 2 \text { LU }\end{array}$ \\
\hline 10 & 48 & $\mathbf{F}$ & $\begin{array}{l}\mathrm{R}-13 \\
\mathrm{~L}-12\end{array}$ & Early & $\begin{array}{l}\mathbf{R} 205 \\
\text { L } 200\end{array}$ & $\begin{array}{l}\text { L eye: scotopic } \\
a \text { wave } 250 \mu \mathrm{V} \\
\text { scotopic } b \text { wave } 375 \mu \mathrm{V}\end{array}$ & $\begin{array}{l}\alpha \text { point missing } \\
L \text { eye: Normal threshold }\end{array}$ \\
\hline 11 & 58 & $\mathbf{M}$ & $\begin{array}{l}\mathbf{R}-14 \\
\mathbf{L}-12\end{array}$ & $\begin{array}{l}\text { Early to } \\
\text { moderate }\end{array}$ & $\begin{array}{l}\text { R } 208 \\
\text { L } 199\end{array}$ & $\begin{array}{l}\text { L eye: scotopic } a \text { wave } \\
400 \mu \mathrm{V} \\
\text { scotopic } b \text { wave } 500 \mu \mathrm{V}\end{array}$ & $\begin{array}{l}\alpha \text { point missing } \\
L \text { eye: Normal threshold }\end{array}$ \\
\hline
\end{tabular}

TABLE IX

Summary of Results in Cases of Uniocular Degenerative Myopia

\begin{tabular}{|c|c|c|c|c|c|c|c|c|c|c|c|c|}
\hline \multirow{2}{*}{$\begin{array}{c}\text { Case } \\
\text { No. }\end{array}$} & \multirow{2}{*}{$\begin{array}{l}\text { Age } \\
\text { (yrs) }\end{array}$} & \multirow{2}{*}{ Sex } & \multicolumn{5}{|c|}{ Normal } & \multicolumn{5}{|c|}{ Myopic } \\
\hline & & & V.A. & Refraction & $\begin{array}{c}\text { EOG } \\
\text { (per } \\
\text { cent.) }\end{array}$ & ERG & $\begin{array}{c}\text { Dark } \\
\text { Adapta- } \\
\text { tion }\end{array}$ & V.A. & Refraction & $\begin{array}{c}\text { EOG } \\
\text { (per } \\
\text { cent.) }\end{array}$ & ERG & $\begin{array}{c}\text { Dark } \\
\text { Adapt- } \\
\text { tion }\end{array}$ \\
\hline 1 & 6 & $\mathbf{M}$ & $6 / 9$ & 0 & 289 & & & C.F. & -24 & 262 & & \\
\hline 2 & 9 & $\mathrm{~F}$ & $6 / 9$ & 0 & 200 & & $\mathbf{N}$ & $6 / 60$ & -10 & 182 & & $\mathrm{n}$ \\
\hline 3 & 42 & $\mathrm{~F}$ & $6 / 5$ & 0 & 227 & $\mathbf{N}$ & $\mathbf{N}$ & $6 / 60$ & -19 & 209 & $\begin{array}{c}\text { Abnormal } \\
a \text { wave }\end{array}$ & $\mathrm{n}$ \\
\hline 4 & 58 & $F$ & $6 / 5$ & +2 & 182 & $\mathbf{N}$ & $\mathbf{N}$ & H.M. & -18 & 166 & $\begin{array}{c}\text { Enlarged } \\
a \text { wave }\end{array}$ & $\mathrm{n}$ \\
\hline
\end{tabular}


that the early histological changes in degenerative myopia consist of a general thinning of the choroid and changes in the region of the retinal pigment epithelium (Blach, 1965). The degenerative changes affect the outer layers of the retina earlier than the inner layers.

An important finding of this investigation is that the EOG values of patients with degenerative myopia are subnormal. This difference between the normal and myopic eye is particularly well demonstrated in uniocular myopia. Although the EOG ratio of the myopic eye was not necessarily below the lower limit of normal, the difference between the normal and the myopic eye was of the order of 20 points, and this suggests a difference of retinal function between the two eyes. Because of the difficulty in the clinical grading of the fundus in degenerative myopia, the relationship between the EOG and the state of the fundus was indefinite. However, when the average EOG findings in early, moderate, and severe myopia were compared, there was a significant difference between the EOG ratios in early and severe myopia (Table VI). Although these findings suggest a relationship between the EOG ratio and the degree of degeneration, results from any one patient did not necessarily show this relationship as there was a considerable amount of individual variation.

In order to obtain a normal light-rise in an EOG, four factors at least appear to be required (Arden and Kelsey, 1962 a, b): functioning rods, functioning pigment epithelium, contact between pigment epithelium and neural layers, and an adequate choroidal blood supply.* A subnormal EOG suggests an abnormality in these regions, and the findings in the myopic patients are in accord with the known pathology of this condition.

Another important finding of this investigation is the sensitivity of the ERG to the retinal damage in degenerative myopia. Our findings are in agreement with those of other authors (Karpe and Rendahl, 1952; Franceschetti and others, 1960; François and de Rouk, 1954) that the $b$ wave is reduced, but only Ponte (1962) has described the negative waveforms found consistently in this survey.

The site of origin of the various components of the ERG is becoming well-established (Brown and Wiesel, 1961; Brown and Watanabe, 1962; Arden and Brown, 1965) and this knowledge helps in interpreting the ERG changes in patients with degenerative myopia. In advanced cases where all the retinal layers are affected by the degenerative process the $a$ and $b$ waves are greatly reduced. In the early and moderate cases the striking finding is the large size of the $a$ wave relative to the $b$ wave; in many cases the $b$ wave appears depressed in amplitude and the $a$ wave increased. However, for the total group, the correlation between the $a$ and $b$ waves is positive, suggesting that both waves are affected by the degenerative process, and this might indicate an early involvement of the receptors. Some support for this hypothesis arises from the studies of chloroquine retinopathy (Arden and Kolb, 1964; Kolb, 1965) where the ERG results show some similarity to the present findings. Chloroquine is said to accumulate in the pigment epithelium and in the receptor cells, and similarly in degenerative myopia the pathological process appears to start

* In myopia the second and fourth of these factors are suspect. Certainly in chloroquine retinopathy, where the electrical findings are similar to those in myopia, the pigment epithelium is known to be involved (Kolb, 1965; Meier-Ruge, 1965). 
in the choroid and pigment epithelium with early involvement of the receptor cells.

This damage to the pigment epithelium and receptors in myopic patients is not the sole cause of the ERG waveforms described, for some cases gave "supernormal" or "negative" ERGs. It appears probable that the ERG changes found in this investigation are the result of a number of pathological processes: vascular insufficiency in the choroid and retina, as shown by narrowing, stretching, and obliteration of some blood vessels; metabolic changes in the pigment epithelium resulting in degeneration of these cells and consequent degeneration of the receptor cells. For any one patient, one or more of these processes may predominate, and this could explain the variation in the findings, and particularly the lack of correlation between the ERG and EOG results.

Dark adaptation was found to be affected in the patients with the most severe degeneration of the retina, and the overall decrease of scotopic sensitivity can be explained by degeneration of large areas of retina. Other authors (Lohman, 1907; Benit, 1927; Braendstedt, 1935; Matthey, 1933; Jayle and Ourgaud, 1950) have related loss of rod sensitivity to the degree of myopic degeneration, but this could not be established in the small numbers in the present study. The absence of the $\alpha$ point has been noted by Jayle and Ourgaud (1950).

The observation that the EOG ratio in patients with pigmented eyes was different from that in patients with non-pigmented eyes is interesting, but so far we have been unable to explain this difference, particularly as there is no difference in the EOG findings from the normal in albino patients (Gouras and Gunkel, 1963; Kolb, 1965).

We have attempted to relate the clinical appearance in degenerative myopia to the pathological findings and to the results of the electrical tests, and a provisional scheme for these relationships is presented in Table X. The various electrical tests can, therefore, give us some idea of the overall state of the myopic eye. Whether this information will be of prognostic value is not known, but it appears unlikely that it

TABLE X

Relationship between Clinical Appearance, Pathological Findings, and Results of Electrical Tests in Degenerative Myopia

\begin{tabular}{l|c|c|c|c|c|c}
\hline $\begin{array}{c}\text { Clinical } \\
\text { Appearance }\end{array}$ & $\begin{array}{c}\text { Changes in } \\
\text { Pigment Epithelium }\end{array}$ & $\begin{array}{c}\text { Changes in } \\
\text { Rods and Cones }\end{array}$ & $\begin{array}{c}\text { Changes in } \\
\text { Inner Retina }\end{array}$ & EOG & ERG & $\begin{array}{c}\text { Dark } \\
\text { Adaptation }\end{array}$ \\
\hline Normal & $\mathrm{n}$ & $\mathrm{n}$ & $\mathrm{n}$ & $\mathrm{n}$ & $\mathrm{n}$ & $\mathrm{n}$ \\
\hline Early & $*$ & $\mathrm{n}$ & $\mathrm{n}$ & $*$ & $\mathrm{n}$ & $\mathrm{n}$ \\
\hline $\begin{array}{c}\text { Early/ } \\
\text { Moderate }\end{array}$ & $*$ & $\mathrm{n}$ & $\mathrm{n}$ & $*$ & $a+$ & $\mathrm{n}$ \\
\hline Moderate & $* *$ & $*$ & $\mathrm{n}$ & $* *$ & $\begin{array}{c}a+, \\
b-\end{array}$ & $\mathrm{n}$ \\
\hline $\begin{array}{c}\text { Moderate/ } \\
\text { Severe }\end{array}$ & $* * *$ & $* *$ & $\mathrm{n}$ & $* * *$ & $\begin{array}{c}a * * \\
b-\end{array}$ & $*$ \\
\hline \begin{tabular}{c} 
Severe \\
\hline
\end{tabular} & $* * *$ & $* * *$ & $*$ & $* * *$ & $\begin{array}{c}a * \\
b\end{array}$ & $* *$ \\
\hline
\end{tabular}

* Slight abnormality ** definite abnormality $\quad * * *$ gross'abnormality 
will help in distinguishing simple from potentially degenerative myopia, for the electrical changes will precede the clinical changes by only a small interval of time.

\section{Summary}

A series of 35 patients with degenerative myopia was examined.

The main conclusions show that the EOG values are definitely reduced in degenerative myopia. This was confirmed in studies on patients with uniocular myopia. The reduction was to some extent related to the degree of chorio-retinal degeneration and could be explained pathologically by the early involvement of the region of the retinal pigment epithelium in this disease. The ERGs were abnormal in a variety of ways, the most usual being a deep $a$ wave and a reduced $b$ wave, both waves probably being primarily affected. The correlation between the EOG and ERG was not significant. The variation in the ERG results was explained on pathological grounds by the variable proportions of chorio-retinal vascular change, retinal pigment epithelium degeneration and receptor changes found in degenerative myopia. Dark adaptation was abnormal in one-third of cases representing those with the severest clinical changes and therefore with the greatest receptor degeneration.

\section{REFERENCES}

Arden, G. B., and Barrada, A. (1962). Brit. J. Ophthal., 46, 468.

—_, - - and KeLSEY, J. H. (1962). Ibid., 46, 449.

and Brown, K. T. (1965). J. Physiol. (Lond.), 176, 429.

and KelSEY, J. H. (1962a). Ibid., 161, 189. , (1962b). Ibid., 161, 205.

and Kolb, H. (1964). Exp. Eye Res., 3, 334.

BENIT (1927). Quoted from JAYLE and others (1959).

BlACH, R. K. (1965). "The Nature of Degenerative Myopia". M.D. Thesis, University of Cambridge.

$\longrightarrow$, JAY, B., and MacFaul, P. (1965). Proc. roy. Soc. Med., 58, 109.

BRAENDSTEDT (1935). Quoted from JAYLE and others (1959).

Brown, K. T., and Watanabe, K. (1962). Nature (Lond.), 196, 547. and Wiesel, T. N. (1961). J. Physiol. (Lond.), 158, 257.

DUKe-EldER, S. (1949). "Text-book of Ophthalmology", vol. 4, p. 4281. Kimpton, London.

Franceschetti, A., Dieterle, P., and Schwartz, A. (1960). In "Electroretinographia" (Symposium, LuhaČovice, 1959), pp. 247-252. Purkyně, Brně. [Acta Fac. med. Univ. Brunensis, 4 ].

François, J., and De Rouck, A. (1954). Bull. Soc. belge Ophtal., 107, 323. , Verriest, G., and De Rouck, A. (1956). Brit. J. Ophthal., 40, 108.

Gouras, P., and Gunkel, R. D. (1963). Arch. Ophthal. (Chicago), 70, 629.

JAYLE, G. R., and BOYER, R. L. (1960). In "Electroretinographia" (Symposium Luhačovice, 1959), pp. 263-272. Purkyně, Brně. [Acta Fac. med. Univ. Brunensis, 4]. and Ourgaud, A. G. (1950). "La vision nocturne et ses troubles". Masson, Paris.

$\longrightarrow$, Baisinger, L. F., and Holmes, W. J. (1959). "Night Vision", pp. 274-280. Thomas, Springfield, Ill.

KARPE, G. (1945). Acta ophthal. (Kbh.), Suppl. 24, pp. 73-75.

and RENDAHL, I. (1952). Ibid., 30, 303.

Kolb, H. (1965). Brit. J. Ophthal., 49, 573.

LOHMAN (1907). Quoted from JAYLE and others (1959).

MATTHEY (1933). Idem.

MeIER-Ruge, W. (1965). A.M.A. Arch. Ophthal., 73, 540.

PONTE, F. (1962). Boll. Oculist., 41, 739. 